\title{
TEN-YEAR VARIATIONS IN POPULATION STRUCTURE OF PINK-SHRIMP IN A SOUTHWESTERN ATLANTIC BAY AFFECTED BY HIGHWAY CONSTRUCTION
}

\author{
Felipe Freitas Jr. ', Hélio A. A., Fracasso ${ }^{2}$, Joaquim O. Branco ${ }^{l}$ and Martin L. Christoffersen ${ }^{3 *}$ \\ ${ }^{1}$ Centro de Ciências Tecnológicas da Terra e do Mar, CTTMar - UNIVALI \\ (Caixa Postal 360, 88302-202 Santa Catarina, SC, Brasil) \\ ${ }^{2}$ Universidade Federal de São Carlos-UFSCar \\ Departamento de Hidrobiologia \\ (13565-905 São Carlos, SP, Brasil) \\ ${ }^{3}$ Universidade Federal da Paraíba \\ Departamento de Sistemática e Ecologia \\ (58059-900 João Pessoa, PB, Brasil) \\ *E-mail: mlchrist@dse.ufpb.br
}

\begin{abstract}
A B S TR ACT
Objectives: Population structures of Farfantepenaeus brasiliensis and F. paulensis, consisting mainly of juveniles, were evaluated during the construction of an expressway along a mangrove area. Estuarine regions in southern Brazil function as sites for reproduction, nursery and growth of a variety of organisms, including two of the most important species of shrimp for fisheries in the southwestern Atlantic. Shrimps were collected in Saco dos Limões creek, Baía-Sul, Florianópolis, State of Santa Catarina, four times a year, by day and night, between 1997 and 2006. Fluctuations in the abundances of shrimp appear to be related to their life cycles, with largest abundances in Summer and Spring, rather than to impacts promoted by dredging activities during the expressway construction.
\end{abstract}

\section{RESUMO}

Objetivos: A estrutura populacional de Farfantepenaeus brasiliensis e F. paulensis, consistindo principalmente de juvenis, foi avaliada durante a construção de uma via expressa ao longo de uma área de manguezais. Regiões estuarinas do sul do Brasil funcionam como locais de reprodução, berçários e de crescimento de uma variedade de organismos, incluindo duas das mais importantes espécies de camarões comerciais do Atlântico Sul Ocidental. Camarões foram coletados no Saco dos Limões, Baía Sul, Florianópolis, Estado de Santa Catarina, trimestralmente, de dia e de noite, entre 1997 e 2006. Flutuações em abundâncias de camarões podem estar relacionados aos seus ciclos de vida, com as maiores abundâncias no verão e primavera, ao invés de impactos promovidos pelas atividades de dragagem durante a construção da via expressa.

Descriptors: Shrimp, Farfantepenaeus brasiliensis, Farfantepenaeus paulensis, structure of populations, environmental impacts, southern Brazil.

Descritores: Camarões, Farfantepenaeus brasiliensis, Farfantepenaeus paulensis, estrutura populacional, impactos ambientais, sul do Brasil.

\section{INTRODUCTION}

Coastal environments such as creeks, bays and estuaries are notable for their high productivity, their importance as places for reproduction, as nurseries and for the growth of a variety of organisms, and for their susceptibility to human impact (SIGNORET, 1974; BRANCO; VERANI, 1998a; ALBERTONI et al., 1999, 2003). In these ecosystems, shrimps represent one of the most important fishery resources exploited both worldwide and along the coast of Brazil (D' INCAO, 1991; VALENTINI et al., 1991; ALBERTONI et al., 2003; CASTRO et al. 2005; GUSMÃO et al., 2005; LEITE; PETRERE, 2006a, 2006b; ROBERT et al., 2007).

In southeastern Brazil, shrimp fisheries are well developed, mainly as regards the stocks of the pink shrimp (Farfantepenaeus brasiliensis Latreille, 1970 and $F$. paulensis Pérez-Farfante, 1967) and the Atlantic seabob shrimp (Xiphopenaeus kroyeri Heller, 1862) (VALENTINI et al., 1991; D' INCAO et al., 2002). 
In the Conceição Lagoon, located in Florianópolis, Santa Catarina, these pink shrimps represent an important fishery resource for traditional small-scale fishing (BRANCO; VERANI, 1998a, 1998b; LUCHMANN et al., 2008).

Recent studies on captures of the pink shrimp have demonstrated that these species are over-fished (MMA, 2004). This situation results from the increasing pressure of industrial fisheries on adult stocks in the ocean, from a disregard for minimum capture size in estuarine fisheries by artisanal fishers, and from the degradation of these nursery areas (VILLELA et al., 1997; D' INCAO et al., 2002; LEITE; PETRERE, 2006a, 2006b).

The reproduction of these shrimps occurs all year round in the open sea, between depths of from 40 to 100 meters. Post-larvae enter estuaries, where growth occurs, and pre-adults migrate from these nurseries to the reproductive zones in the sea (D' INCAO, 1991; BRANCO; VERANI, 1998a, 1998b).

Baía-Sul (South Bay), with an area of 181 $\mathrm{km}^{2}$, is an important feature of the coastal region of the State of Santa Catarina, with mangroves, an extractivist marine reserve, lagoons and a large number of islands and beaches, used for leisure, tourism, fishing, the cultivation and commercialization of mollusks, thus representing a source of food and income for a significant proportion of the local population (RESGALLA JR., 2001; SOUZACONCEIÇÃO et al., 2005; SCHETTINI et al., 2000). However, this ecosystem is suffering serious anthropic impact resulting from domestic effluents and dredging activities (RESGALLA JR., 2001). The government of the State of Santa Catarina extracted about $8.5 \times 10^{6} \mathrm{~m}^{3}$ of sand during the period from 1995 to 1997 from a bank located in the center of this creek, in order to build an embankment of $15.9 \mathrm{~km}$ that culminated in the construction of the southern expressway connecting Santa Catarina with the continent.

According to Von Dolah et al. (1984) and Newell et al. (2003; 2004), macrocrustaceans are usually only partially affected in areas subject to dredging, because their mobility permits them to flee the impacted areas, while the infauna composed of polychaetes, oligochaetes, mollusks and small crustaceans is usually most affected.

Considering the impact of the construction of this public expressway in Saco dos Limões creek (Baía-Sul), the aim of this paper was to analyze the population structure of $F$. brasiliensis and $F$. paulensis, to monitor the life cycles of these species, and to ascertain whether their abundance and population structures are stable over the years.

\section{Materials ANd Methods}

Saco dos Limões creek is located in Baía-Sul $\left(27^{\circ} 36^{\prime}-27^{\circ} 39^{\prime} \mathrm{S}\right.$ and $\left.48^{\circ} 33^{\prime}-48^{\circ} 31^{\prime} \mathrm{W}\right)$ (Fig. 1). The bottom is composed of sand-mud mixed with biodetritic material, the creek having shallow waters of high salinity; the local hydrodynamics are controlled by the tidal regime and the prevailing southerly and northeasterly winds (RESGALLA JR., 2001; SOUZACONCEIÇÃ̃O et al., 2005; SCHETTINI et al., 2000).

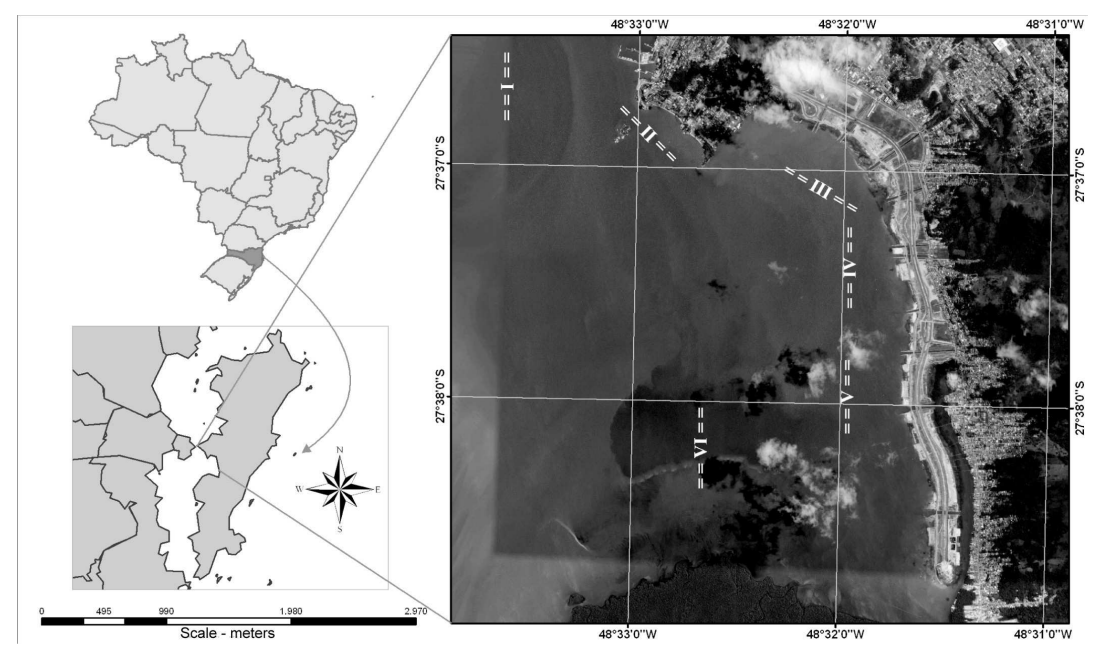

Fig. 1. Map of sampling sites. Upper left, Brazil, with the State of Santa Catarina enhanced; lower left, close-up of the municipality of Florianópolis, including the Island of Santa Catarina, which delimits two bays between the island and the continent, Baía-Norte (North Bay) and BaíaSul (South Bay); right, close-up of upper right-hand corner of Baía-Sul (Saco dos Limões creek), showing the six collecting areas (I-VI) (Source: Geo-processing Lab - UNIVALI). 
Shrimps were collected in six areas in the creek (Fig. 1). These areas were established along the creek in order to take a representative sample of the entire area in terms of depth, freshwater drainage, and dredging activities. These areas are described in Table 1. Sampling was done every three months, during the day and at night, over the period from 1997 to 2006 (excepting 1998 and 1999). Specimens were captured with two double rigged trawling nets, with $7.5 \mathrm{~m}$ total length and $5.5 \mathrm{~m}$ wide. The net mesh was $3 \mathrm{~cm}$ in the body of the nets and $2 \mathrm{~cm}$ in the collecting sac. The nets were pulled by a whaler for 10 minutes at a mean velocity of 2.0 knots. Specimens from both nets were pooled (we assumed that a single collecting device was used), providing the total number of individuals collected during 10 mins in each sub-area.

Table 1. Area descriptions of samplings during years 19972006, adapted from Souza-Conceição et al. (2005).

\begin{tabular}{|c|c|c|}
\hline Area & Depth & Characters \\
\hline \# I & 2 to 8 meters & $\begin{array}{l}\text { In this area an increase in salinity is } \\
\text { observed due to sea water circulation. }\end{array}$ \\
\hline \# II & 2 to 4 meters & $\begin{array}{l}\text { Presents greater exposure to weather, } \\
\text { and has high salinity due to sea water } \\
\text { circulation. }\end{array}$ \\
\hline \# III & 2 meters & $\begin{array}{l}\text { Area protected from the wind, with } \\
\text { great influence of continental flow } \\
\text { from galleries and rivers. }\end{array}$ \\
\hline \# IV & 2 meters & $\begin{array}{l}\text { The flow of surface water from small } \\
\text { rivers and galleries has great } \\
\text { influence on salinity and nutrient } \\
\text { viability. }\end{array}$ \\
\hline$\# \mathrm{~V}$ & 2 meters & $\begin{array}{l}\text { Area with greater influence of } \\
\text { Tavares river discharge, with low } \\
\text { salinity, high turbidity and nutrient } \\
\text { concentration. }\end{array}$ \\
\hline \# VI & 2 to 8 meters & $\begin{array}{l}\text { Area with maritime conditions and } \\
\text { greater depths, where the extraction of } \\
\text { sediments for the expressway } \\
\text { construction took place. }\end{array}$ \\
\hline
\end{tabular}

No subsamples were obtained. This resulted in a total of 384 samples ( 6 areas $\mathrm{x}$ twice a day $\mathrm{x} 4$ times a year $\mathrm{x} 8$ years). However, these data lack the randomness necessary to detect statistical differences due to specific variables f, 1984; COURTEMANCH, 1994; NORRIS, 1995). Surface water salinities and temperatures were recorded for all the samples, in order to establish seasonal fluctuations for these parameters.

The shrimp species were identified in the laboratory (PÉREZ-FARFANTE, 1978), sex and maturation stage were registered (PÉREZFARFANTE, 1970) and total length (Lt) in centimeters was measured from tip of rostrum to end of telson. The biometry of $F$. brasiliensis was recorded as from 2001, while the biometry of $F$. paulensis covered the period from 1997 to 2006 (except for 2000).

The $\mathrm{c}^{2}$ test, at $5 \%$ level of significance and $\mathrm{n}$ 1 degrees of freedom $(n=2)$, was applied to verify the possible difference between the sexual proportion by class of total length (VAZZOLER, 1996). The relation weight/total length was estimated for males and females (SANTOS, 1978).

The authors opted for one-way ANOVAS because of the lack of data for several days and nights, particularly for the initial study years from 1997 to 2001. The data from these years were obtained from tables containing only the total number of individuals per station (not discriminated by area and period of the day). It was impossible, for this reason, to calculate the mean abundance of shrimp for these years. We have thus only used the total number of shrimp in some of the figures.

The abundance of specimens per station, given by the total number of organisms captured over the two nets' 10 minutes of operation, by year and sampling station, as well as water temperature and salinity, were assessed by one-way ANOVA (ZAR, 1999), being tested for homogeneity of variance (Bartlett test) and normality (Kolmogorov-Smirnov proof).

When significant differences were found, the a posteriori contrast of means (Tukey-Kramer) test was applied to indicate which of them were significantly different.

\section{RESULTS}

Environmental Parameters

The mean surface water temperature presented a uniform pattern of seasonal fluctuation, not differing significantly either over the years $\left(\mathrm{F}_{4-18}=\right.$ $0.227 ; \mathrm{p}>0.05)$ or by collecting area $\left(\mathrm{F}_{5-18}=0.058 ; \mathrm{p}\right.$ $>0.05$ ). The highest mean values were registered in the summer months $\left(26.87^{\circ} \mathrm{C}\right)$ and the lowest in winter $\left(22.83^{\circ} \mathrm{C}\right.$ ) (Fig. 2). There were significant differences among stations $\left(\mathrm{F}_{3-73}=30.53 ; \mathrm{p}<0.05\right)$ due to the lower winter temperatures.

The mean surface water salinity showed the same tendency as temperature to vary seasonally, without there being any significant difference between years $\left(\mathrm{F}_{6-18}=0.657 ; \mathrm{p}>0.05\right)$ or sampling areas $\left(\mathrm{F}_{5-18}=\right.$ $0.241 ; \mathrm{p}>0.05)$. The highest means occurred in summer $(32.43 \%)$ and the lowest in autumn $(27.00 \%)$ (Fig. 2). There were significant differences among stations $\left(\mathrm{F}_{3-146}=10.11 ; \mathrm{p}<0.05\right)$, with lower salinities during winter. 


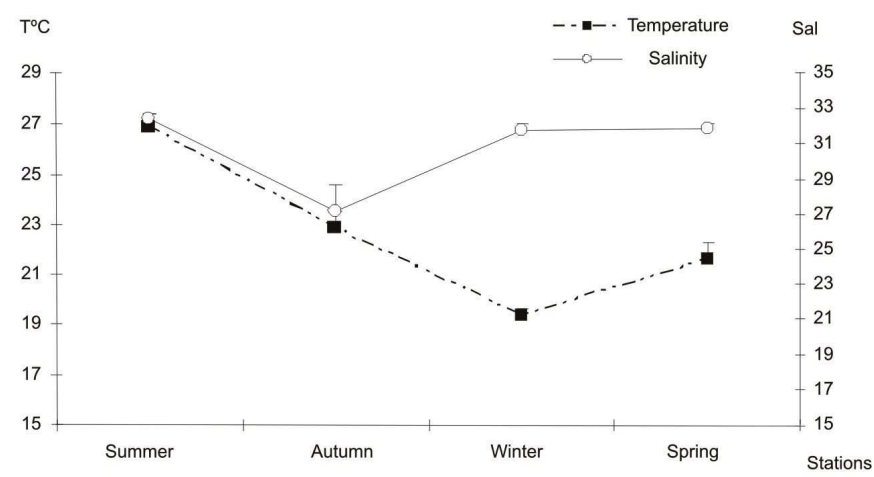

Fig. 2. Mean temporal variation of physico-chemical parameters of surface water in Saco dos Limões (South Bay) during the study period. (Vertical bar $=$ standard error).

Abundance

The abundance of $F$. brasiliensis fluctuated over the years, with significantly smaller captures $\left(\mathrm{F}_{3-26}=3.714 ; \mathrm{p}<0.05\right)$ in $1997(70)$, the highest ones occurring in 2006 (1826) (Fig. 3). In general the largest numbers occurred during the summer months, except for 2002, and the smallest ones in winter and autumn (Fig. 3). Although the largest mean abundances were found in areas VI and V during the night and in the summer and spring months, no significant differences were observed among the collecting sites whether during the day $\left(\mathrm{F}_{5-18}=1.479\right.$; $\mathrm{p}>0.05)$ or at night $\left(\mathrm{F}_{5-18}=0.804 ; \mathrm{p}>0.05\right)$ (Fig. 4).

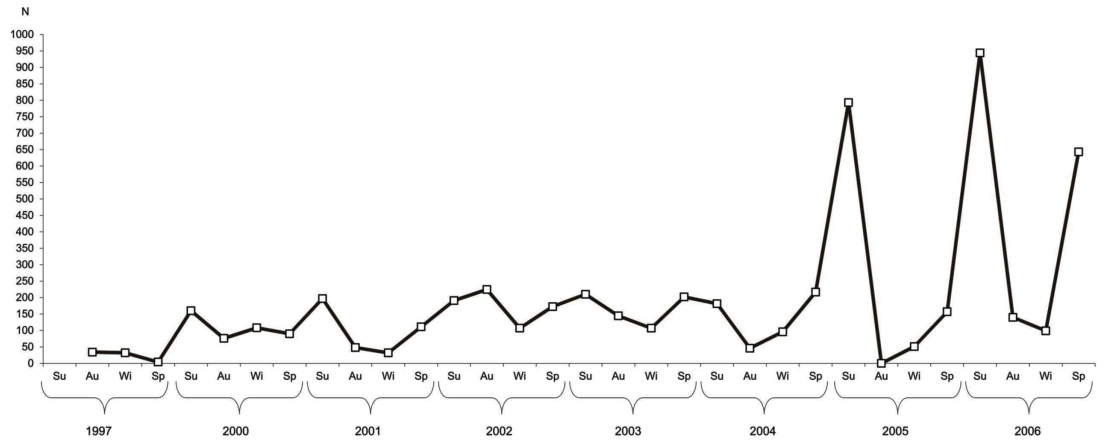

Fig. 3. Seasonal variation in abundance of F. brasiliensis captured in Baía-Sul (South Bay) 1997-2006.

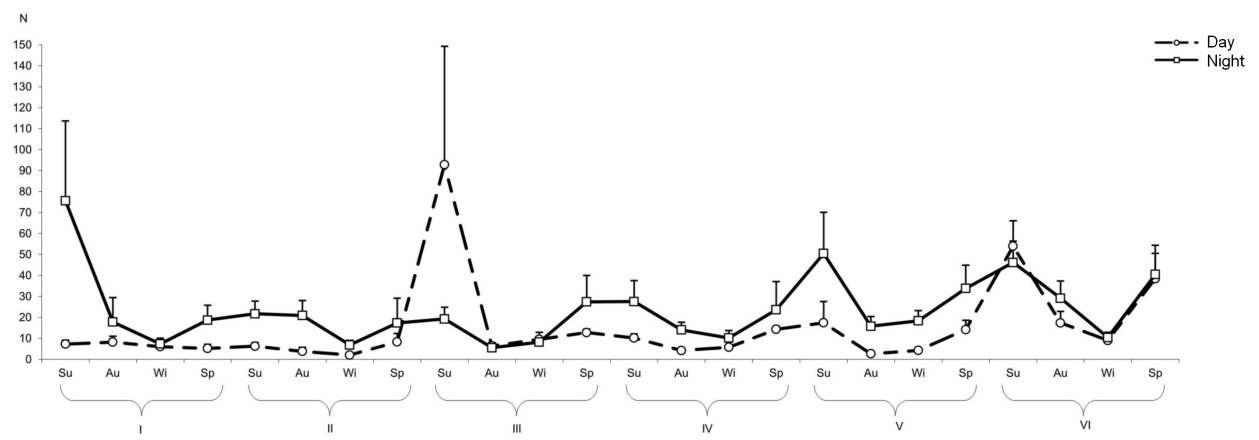

Fig. 4. Seasonal variation in abundance of $F$. brasiliensis captured in areas I, II, III, IV, V and VI, in Saco dos Limões region during the sampling period. 
Only subsequently to 2001 have we been able to discriminate data per area and per period of day, these data being used to produce graphs of mean abundance per area and per period of the day. The number of $F$. paulensis oscillated over the years during the time span studied, with the highest occurrences of shrimp in 2003 and the smallest in 2001, although these values were not significantly statistically different $\left(\mathrm{F}_{7-24}=0.474 ; \mathrm{p}>0.05\right)$ (Fig. 5). In general the largest captures were registered in the summer and spring months, and the smallest in winter (Fig. 5). In areas VI and V the best returns were obtained during winter-spring nights, and the smallest during the day in areas II and I; despite these variations, no significant differences were observed in the abundance of specimens captured during the day $\left(\mathrm{F}_{5-18}=2.583 ; \mathrm{p}>0.05\right)$ or at night $\left(\mathrm{F}_{5-18}=2.451 ; \mathrm{p}>\right.$ 0.05 ) among the collecting areas (Fig. 6).

\section{Sexual Proportion}

The distributions of relative frequencies by total length class of $F$. brasiliensis indicated that the males and females of the species had lengths, respectively, of from 4.0 to $15.0 \mathrm{~cm}$ and 3.0 to 16.0 $\mathrm{cm}$ (Fig. 7). In general, the females were significantly dominant from 3.0 to $6.0 \mathrm{~cm}$ and above $13.0 \mathrm{~cm}$, an inversion in favor of males occurring in the class of $12.0 \mathrm{~cm}$ in 2004 and of $8.0 \mathrm{~cm}$ in 2005 (Fig. 7).

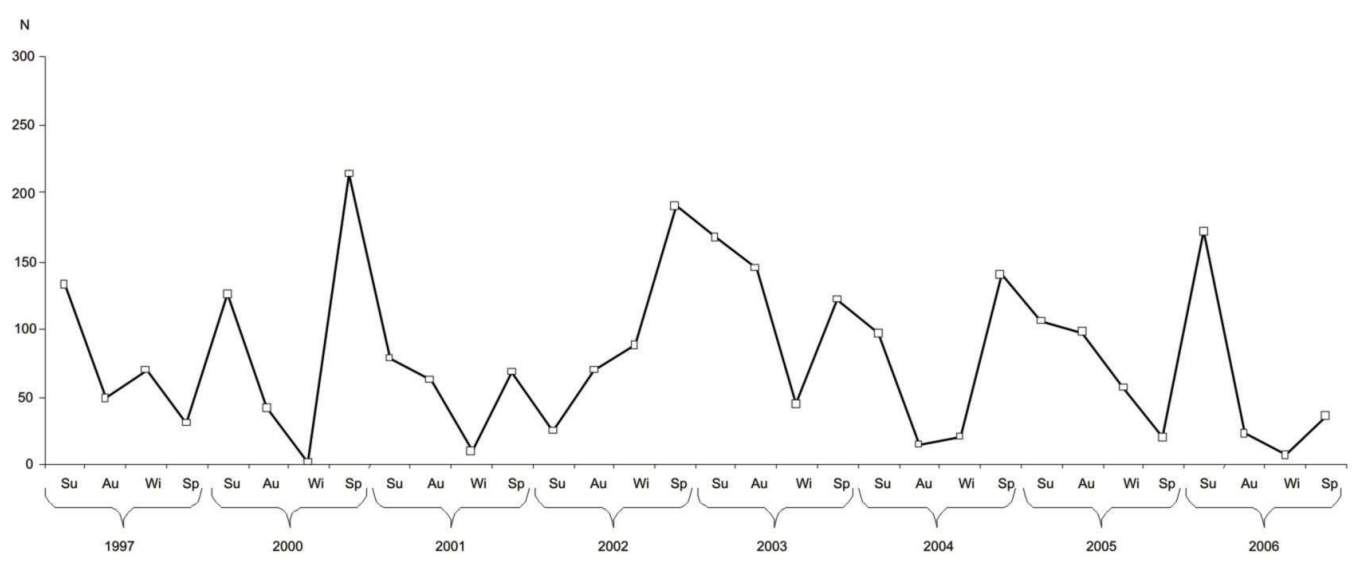

Fig. 5. Seasonal variation in the abundance of F. paulensis in Baía-Sul (South Bay) 1997-2006.

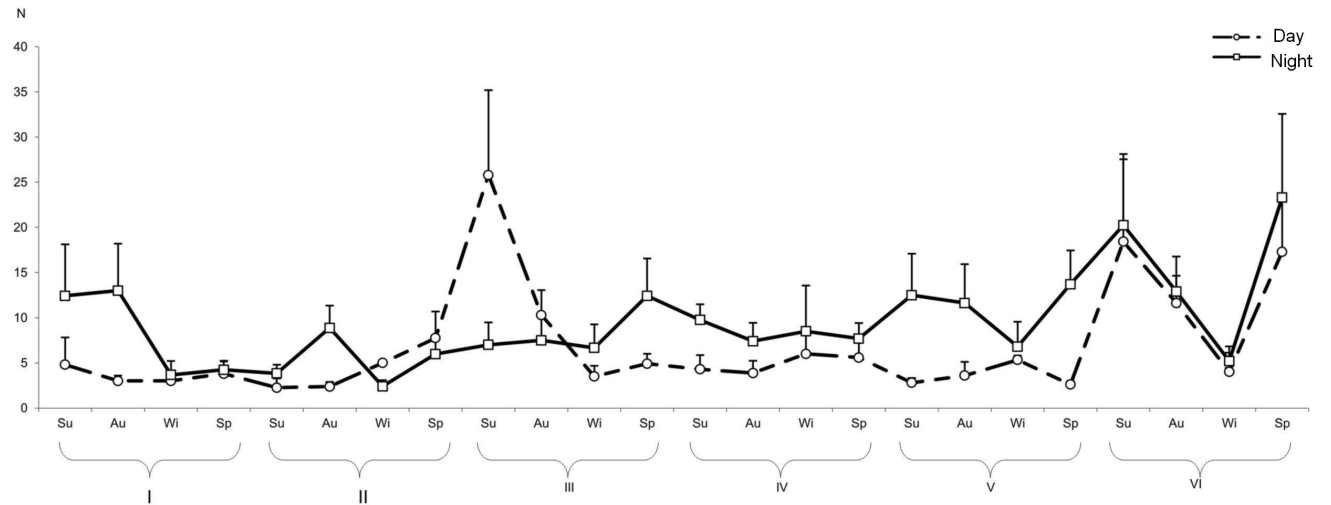

Fig. 6. Seasonal variation in abundance of $F$. paulensis captured in areas I, II, III, IV, V and VI, in Saco dos Limões region during collection period. 
F. paulensis presented a length amplitude varying from 4.0 to $15.0 \mathrm{~cm}$ (males) and from 4.0 to $17.0 \mathrm{~cm}$ (females), with a dominance of these latter up to the $7.0 \mathrm{~cm}$ class and above $13.0 \mathrm{~cm}$ (except in 2001 and 2004), with an inversion in favor of males in 2001, in the 9.0, 10.0 and $13.0 \mathrm{~cm}$ classes (Fig. 8).

Length Structure

Figure 9 shows the distributions of annual frequencies of the length classes by sex in $F$.
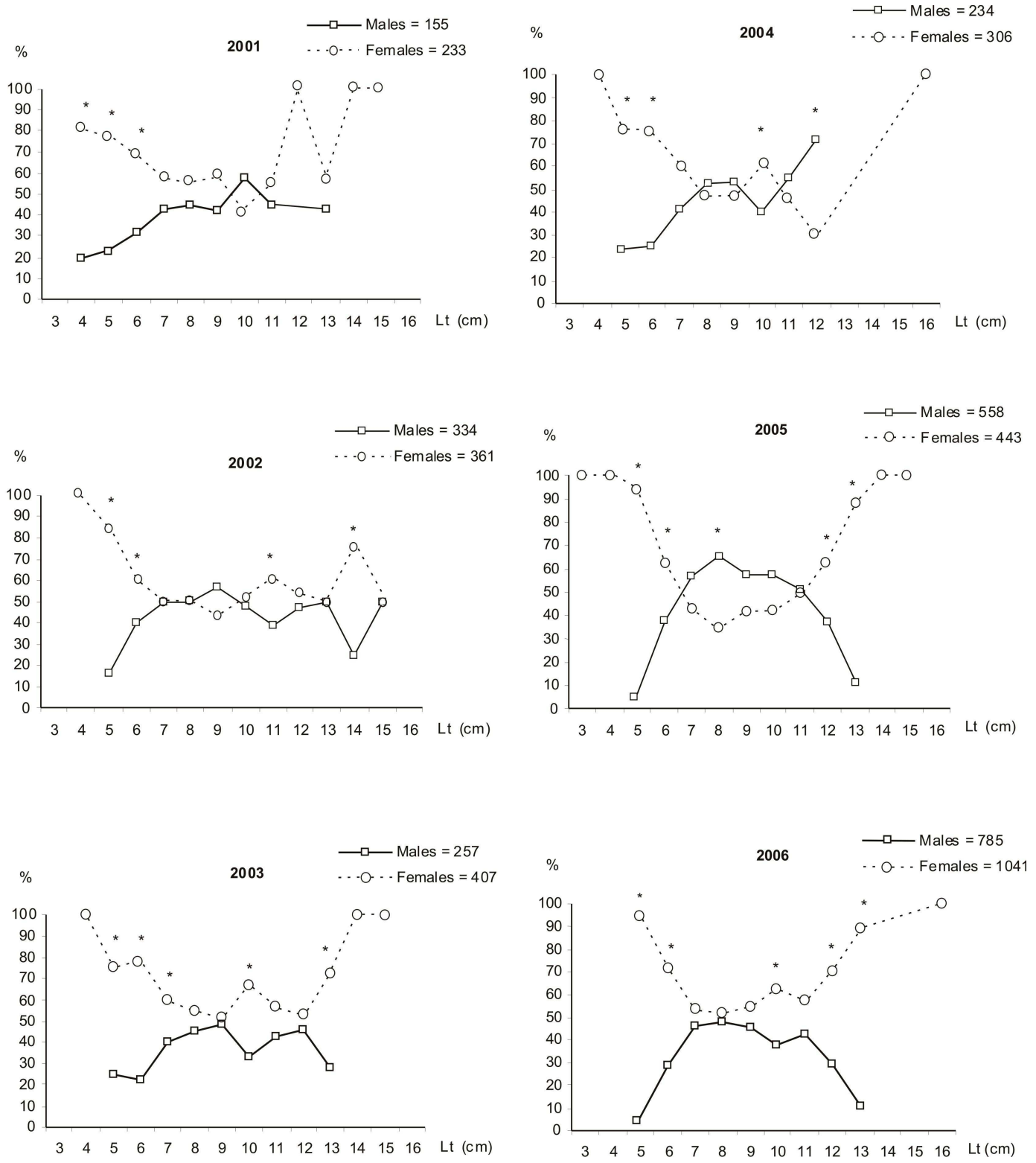

Fig. 7. Frequency of sexual occurrence $(\%)$ of $F$. brasiliensis by length class during 2001-2006. *= significant difference of $\mathrm{c} 2$ test.

brasiliensis, during the period 2001 to 2006 , revealing a similar distribution pattern over the years. Females in general presented total lengths superior to those of males, with increases and oscillations between 3.0 and $8.0 \mathrm{~cm}$, while in males increases in abundance were registered in males between 4.0 and $8.0 \mathrm{~cm}$ (Fig. 9). Despite the oscillations between collecting years, most frequencies of shrimp capture occurred in the 7.0 and $8.0 \mathrm{~cm}$ classes (Fig. 9).

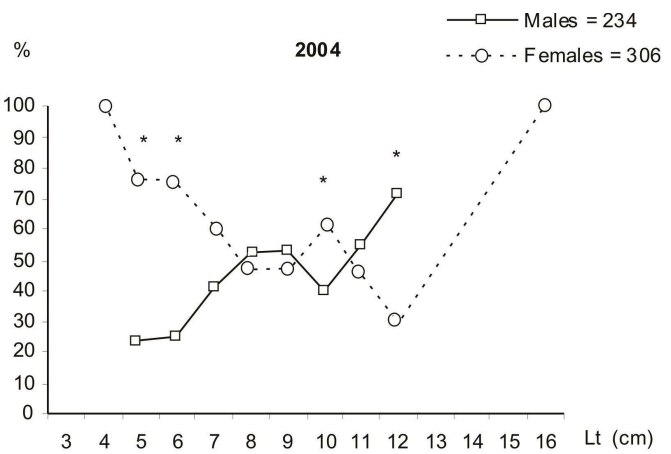



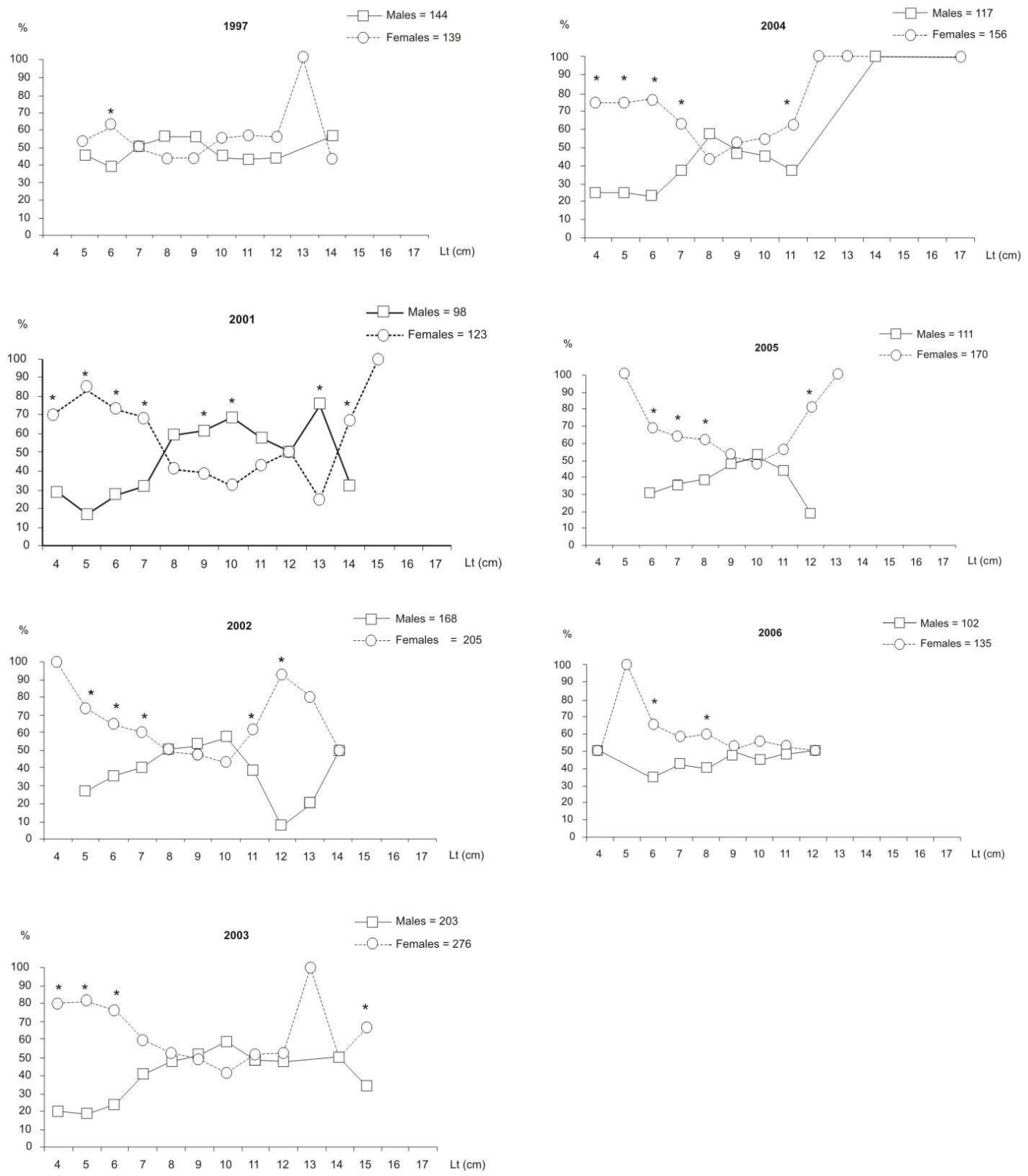

Fig. 8. Frequency of sexual occurrence (\%) of $F$. paulensis by length class during $1997-2006 . *=$ significant difference of c2 test. 

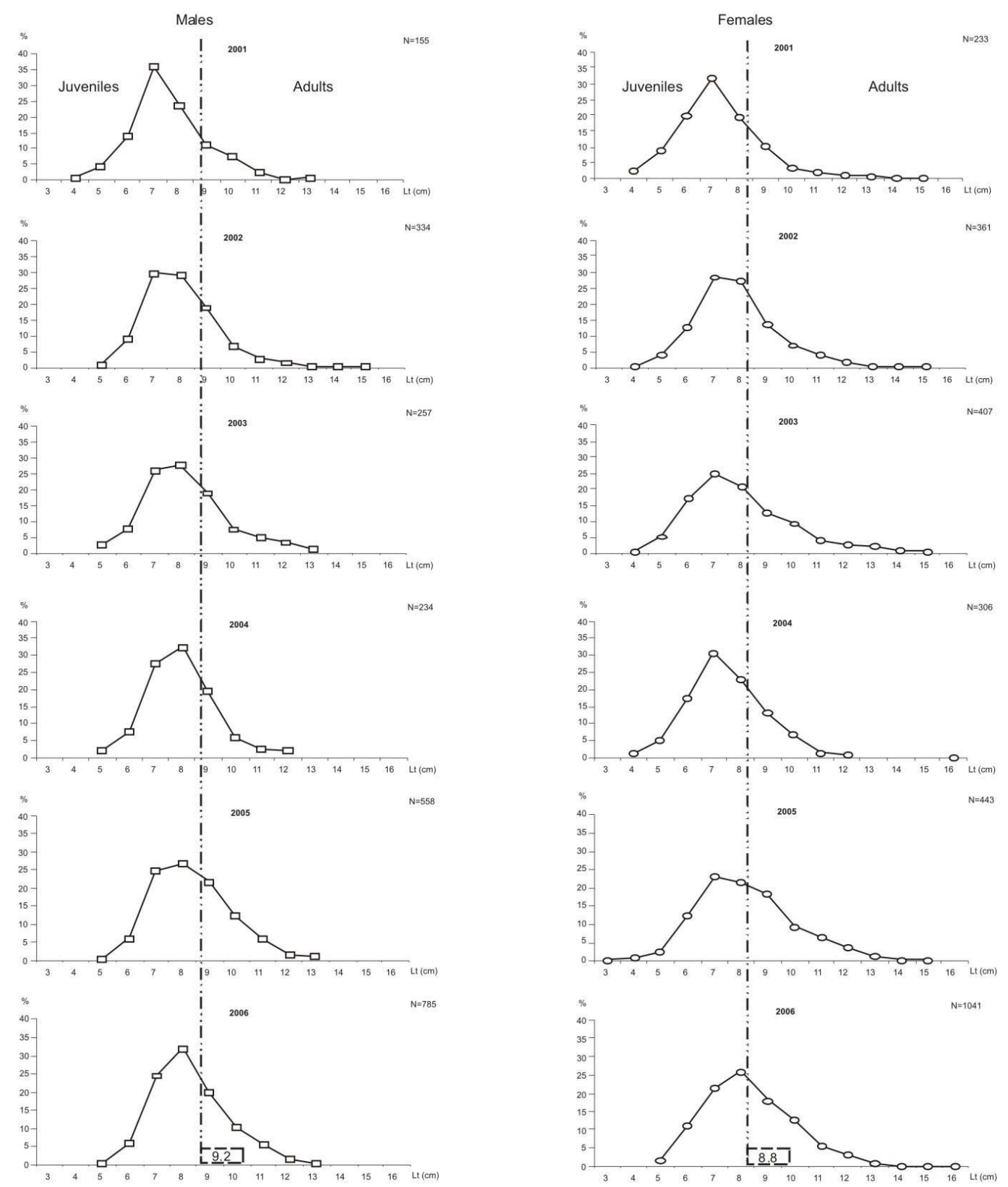

Fig. 9. Distribution of frequency by length class of $F$. brasiliensis during 2001-2006. Hatched line= L50 (BRANCO; VERANI, 1998a).

Analyzing the distributions of the lengths of males and females, together with the size of the first maturation stage, we verified that the population of $F$. brasiliensis was represented mainly by juveniles $(72.2$ - $87.6 \%$ of males and $68.6-85.8 \%$ of females) (Fig. 10). Although present in all seasons of the year in the bay, the largest percentages of juveniles were registered in the spring and autumn months, with intensive individual growth continuing into the winter when the largest sizes were found $(9.24 \pm 1.58 \mathrm{~cm}$ and $9.12 \pm 1.97 \mathrm{~cm}$ ) (Fig. 10). 

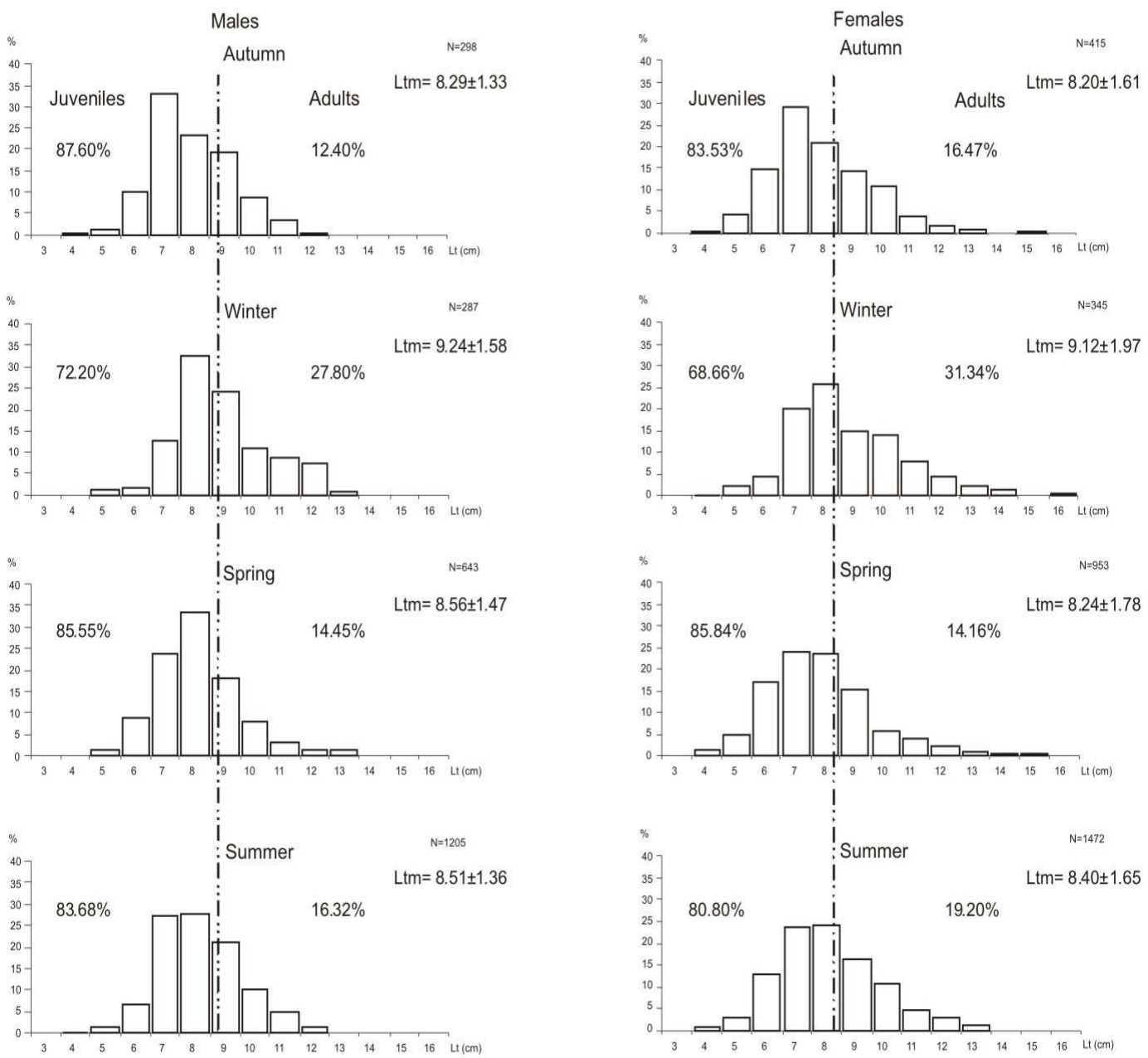

Fig. 10. Seasonal distribution of frequency by length class of $F$. brasiliensis during the years of collection in the Baía-Sul (South Bay) region. Hatched line= L50 (BRANCO; VERANI, 1998a).

The analysis of frequency distribution by length class revealed alterations in the structure and size of the population of $F$. paulensis over the years in which data were collected (Fig. 11). In 1997 the 8.0 to $10.0 \mathrm{~cm}$ classes contributed with the highest frequencies for both sexes, while from 2001 to 2004 the smaller specimens between 6.0 and $9.0 \mathrm{~cm}$ predominated in the samples. In 2005 and 2006, the largest captures were between 8.0 and $11.0 \mathrm{~cm}$, with relatively smaller shrimps (Fig. 11).

Juveniles also predominated in the collections, mainly during the autumn months, while in winter the smallest occurrences and the largest mean lengths were found in the creek: $9.09 \pm 1.61 \mathrm{~cm}$ (males) and $9.08 \pm 1.80 \mathrm{~cm}$ (females) (Fig. 12).

\section{Length/Weight Relationship}

The equations obtained from the length/weight relationship and the determination coefficients indicate that the best associations of these variables were obtained for females, with a negative allometric growth of 2.9195 ( $F$. brasiliensis) and $2.9794(F$. paulensis), while in males the lower $\mathrm{r} 2$ were observed, thus maintaining the negative allometry (Table 2). 

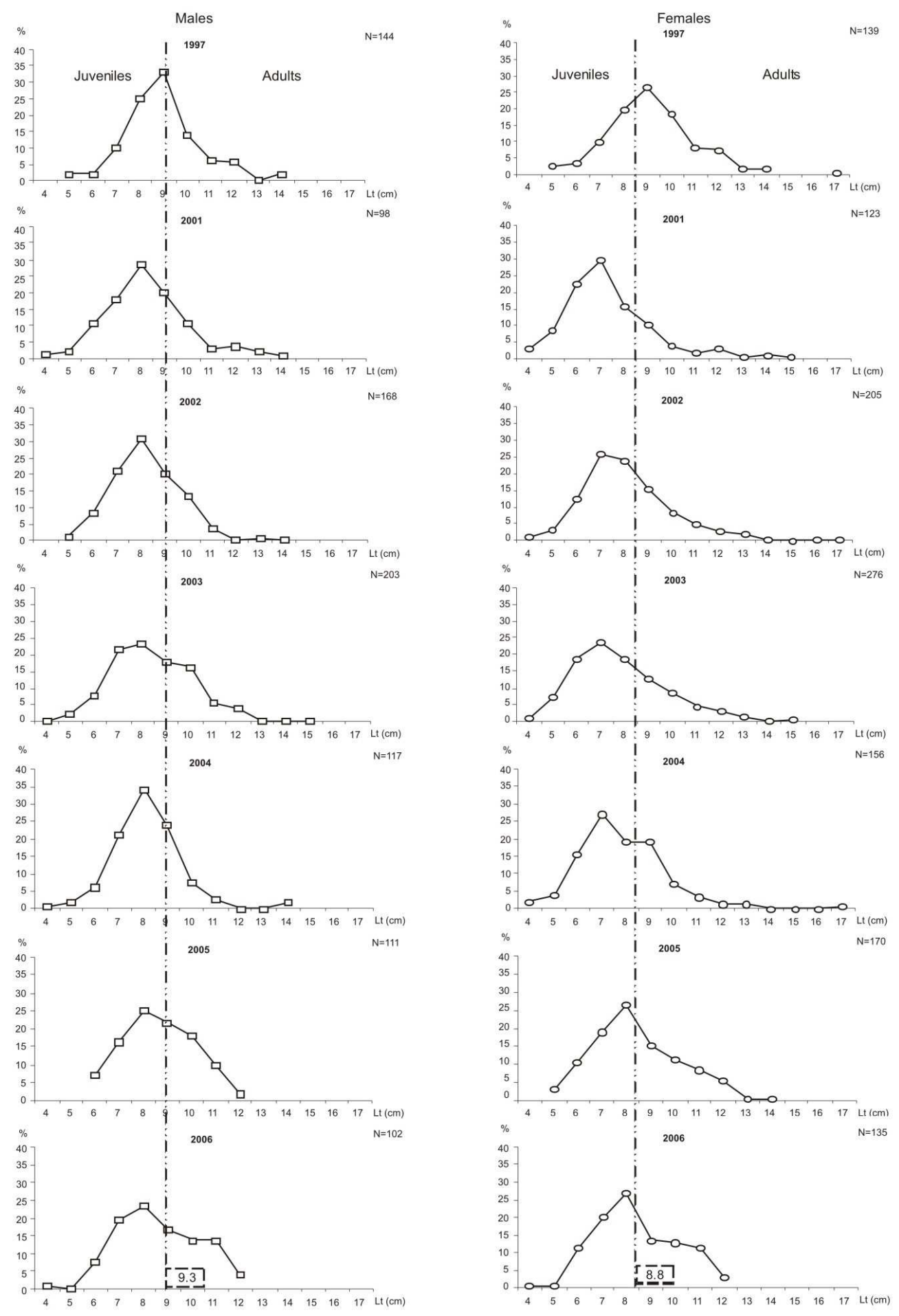

Fig. 11. Distribution of frequency by length class of $F$. paulensis, 1997-2006. Hatched line= L50 (BRANCO; VERANI, 1998b). 

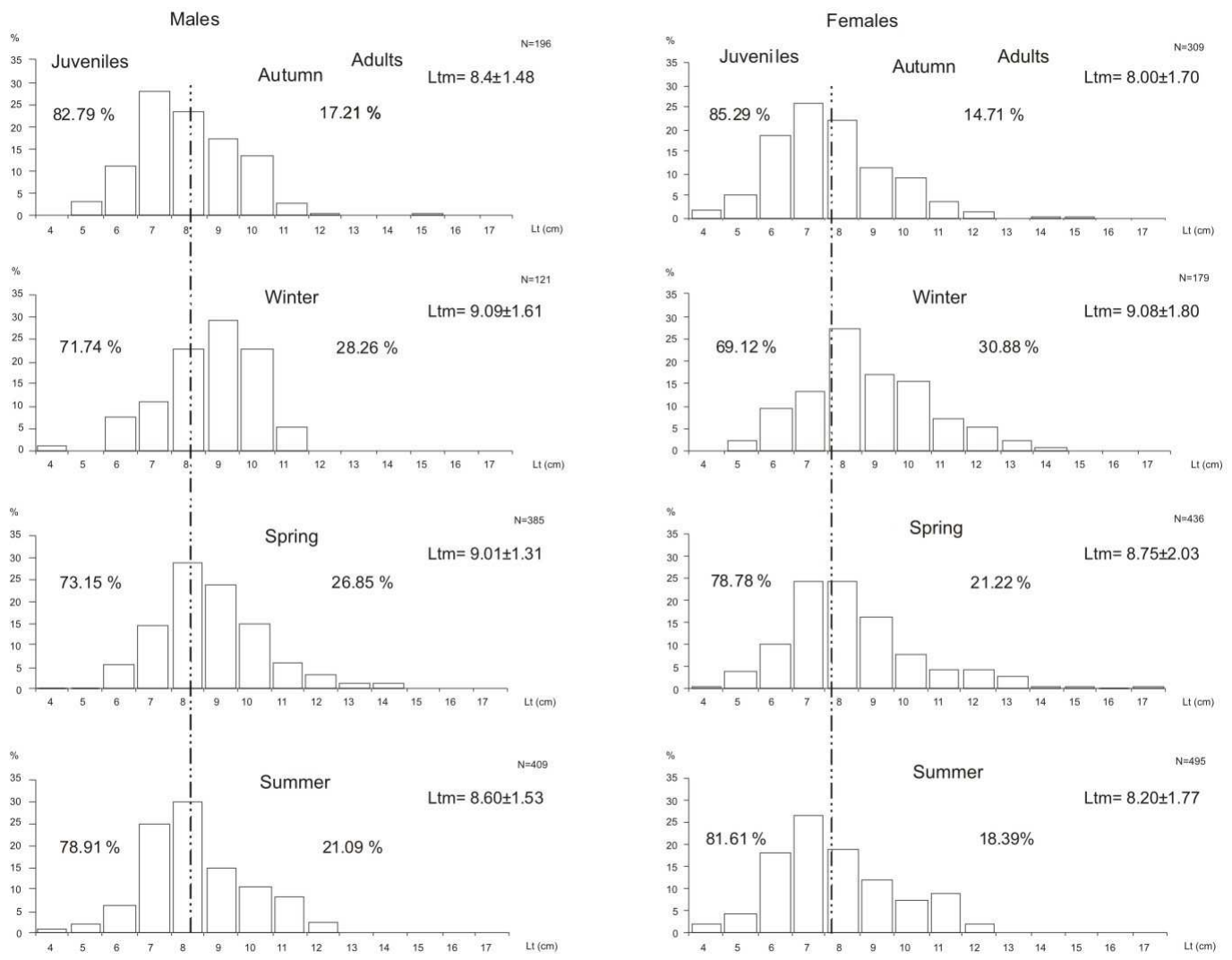

Fig. 12. Seasonal distribution of frequency by length class of $F$. paulensis during the years of collection in the Baía-Sul (South Bay) region. Hatched line $=$ L50 (BRANCO; VERANI, 1998b).

Table 2. Length-weight relationship for males and females of $F$. brasiliensis and F. paulensis in Baía-Sul (South Bay) during the study period.

\begin{tabular}{llcc}
\hline \hline \multicolumn{1}{c}{ Species } & \multicolumn{1}{c}{ Sex } & Equation & $\mathrm{r}^{2}$ \\
\hline \multirow{2}{*}{ F. brasiliensis } & Males & $\mathrm{Wt}=0.01 \mathrm{Lt}^{2.8603}$ & 0.936 \\
& Females & $\mathrm{Wt}=0.0088 \mathrm{Lt}^{2.9195}$ & 0.950 \\
& Males & $\mathrm{Wt}=0.0088 \mathrm{Lt}^{2.9104}$ & 0.942 \\
F. paulensis & Females & $\mathrm{Wt}=0.0077 \mathrm{Lt}^{2.9794}$ & 0.953 \\
& & \\
\hline
\end{tabular}

\section{Discussion}

Seasonal fluctuations in the abundance of penaeid shrimps have been ascribed to water temperature and salinity oscillations (SIGNORET, 1974; PÉREZ-CASTAÑEDA; DEFEO, 2001; LOEBMANN; VIEIRA, 2006; LUCHMANN et al.,
2008), texture of sediment (BRANFORD, 1981) and life cycle of species (MELLO, 1973; FORBES; CYRUS, 1991; NAKAGAKI et al., 1995; PÉREZCASTAÑEDA; DEFEO, 2005).

In the region of Saco dos Limões, $F$. brasiliensis and $F$. paulensis presented the same tendency to seasonal variation, with higher abundances during the summer months. This pattern appears to be associated with high water temperature, availability of food, in the form of particulate organic matter (BRANCO; MORITZ JR., 2001; PÉREZCASTAÑEDA; DEFEO, 2001), besides the contribution of external larvae in this period (RESGALLA JR., 2001). However, for Branco and Verani (1998b) and Luchmann et al. (2008), the autumn was responsible for the largest abundances of $F$. paulensis in the neighborhood of Lagoa da Conceição, indicating a strategy of temporal separation between the two species in these environments. 
Females of $F$. brasiliensis and $F$. paulensis occurred in higher abundances and sizes than males, corroborating what had previously been registered for the southern and southeastern littoral (D' INCAO; CALAZANS, 1978; VILLELA et al., 1997; BRANCO; VERANI, 1998a, 1998b; LEITE; PETRERE, 2006a; ROBERT et al., 2007). These disparities between the sexes may be attributed to growth indices, mortality, longevity, differential migration of sexes and selectivity in fishery activities (D' INCAO, 1990; LINS-OLIVEIRA, 1996; ALBERTONI et al., 2003; PÉREZ-CASTAÑEDA; DEFEO, 2005; LEITE; PETRERE, 2006a, 2006b).

The length/weight relationship rate has been used to facilitate the estimation of the weight of a specimen, inferred from the knowledge of its length, and to determine the type of growth of the species, being regularly used in studies of population dynamics and evaluation of stocks (BRANCO et al., 2002), in which penaeids have a tendency to present differential allometric growth between the sexes (BRANCO, 2005). This pattern was found in populations of $F$. brasiliensis landed in the port of Santos (São Paulo) by Mello (1973) and Leite and Petrere (2006a) and in Lagoa da Conceição (BRANCO; VERANI, 1998a). However, for $F$. paulensis in Lagoa dos Patos it was positive (D' INCAO; CALAZANS, 1978) and in Lagoa da Conceição negative for both sexes (BRANCO; VERANI, 1998b). In the present study both species maintained the negative growth pattern, with a more intensive increment in size than in weight.

From the distribution of frequency by length class, it was possible to ascertain that the populations of $F$. brasiliensis and $F$. paulensis were represented, predominantly, by juveniles, reinforcing the importance of the area as a nursery and repository of pre-adults for the fisheries stock of areas in the open sea (CHAGAS-SOARES et al., 1995; BRANCO; VERANI, 1998a, 1998b). Yet some specimens may remain in the bay until they attain the age of 10 months (D' INCAO, 1991). Environmental alterations of the areas of growth may affect the size of adults (ALBERTONI et al., 2003). Thus, the biometric monitoring of shrimps is fundamental to determine possible changes in the structure of populations submitted to a significant impact (MOURA et al. 2003) such as the dredging undertaken in Saco dos Limões.

In the present study, a relatively stable length pattern was observed in the population of $F$. brasiliensis and alterations were observed in the structure of $F$. paulensis, with a reduction in the size of individuals. In 2005 and 2006, relatively smaller shrimps were captured (Fig. 1), correlating with the reduced occurrence of zoeae and organic matter.

The abundance of $F$. brasiliensis was significantly different as between the years of collection, with the lowest capture indices at the beginning of the sampling period. This fluctuation should possibly be associated with the instability due to the mechanical action of the collecting gear, either by blocking the gills with material in suspension, which occasions high mortality rates (BEMVENUTI et al., 2005), or by the reduced occurrence of zoeae and organic matter, limiting the primary productivity of the environment (RESGALLA JR., 2001), or even by the reduction of sessile prey of low locomotive potential, which are especially vulnerable to the collecting equipment (VON DOLAH et al., 1984; NEWELL et al., 2003, 2004). Despite this initial reduction, the abundance of $F$. brasiliensis recovered in the following years, the capture indices increasing from 2004 onwards.

The proximity of areas V and VI to the mangrove swamps on the Rio Tavares, as well as to the mouth of the Defuntos river, may have contributed to the input of food supplies under sheltered conditions. This may have provided a favorable environment for juvenile growth, reflecting the greater abundance recorded. Moreover, the higher rate of flow in area I (MOLLERI; BONETTI, 2005) was possibly related to the entry and exit of individuals from the Baía-Sul. A similar pattern was found by Branco and Verani (1998a) and Branco and Masunari (2000) for the crab and shrimp populations of the Lagoa da Conceição.

The extraction of sand has apparently had but slight impact on the biology of these two shrimps, but it is difficult to be categorical about this because there are no data prior to 1995 that could serve as control. Due to the high environmental variability in estuarine regions and bays, the fluctuations observed in this study may just as well be a result of the life cycle of these species (FORBES; CYRUS, 1991; BEMVENUTI et al., 2005; PÉREZ-CASTAÑEDA; DEFEO, 2005). The population dynamics in the postimpact period are stable in the long term (despite the natural short term variability) and pink-shrimp stocks do not seem to be declining. The implications for fisheries management are that even extensive bottom dredging operations may not significantly affect fishery stocks of commercial shrimp so long as the normal hydrodynamics of the estuaries concerned are not affected.

\section{Conclusions}

F. brasiliensis population abundance was significantly smaller in 1997 due to environment instability caused by the end of dredging activity. However, the same trend in captures was observed from 1998 to 2003, showing increases in abundance only after 2004. F. paulensis showed abrupt variations over the years studied, but without any significant 
statistical differences among them. Regarding length, $F$. brasiliensis showed little change over the years. On the other hand, $F$. paulensis became smaller over the sampling period.

The expressway construction has not apparently affected either the hydrodynamics of Saco dos Limões creek or, as a result, the free exchange between open sea adult and estuarine juvenile populations. Neither has the dredging or the highway construction significantly affected the population structure of the two commercial species of pink shrimp monitored during the decade in which the expressway was being constructed, at least not in the long run. The seasonal changes in stock sizes do not apparently exceed the normal fluctuations observed in estuarine regions.

Apparently physical disturbances of estuarine environments promote less damage to shrimp stocks than do other potential anthropic influences, such as overfishing pressure on adults and juveniles and excessive discharges of domestic effluents. Excessive fishing and intensive chemical and organic pollution may have more catastrophic consequences for the conservation of commercial shrimp than the temporary dredging and localized damming resulting from the coastal expressway construction which occurred at the beginning of the period of this study.

\section{ACKNOWLEDGEMENTS}

This research was funded by productivity grants made by our National Science Foundation (CNPq, Conselho Nacional de Desenvolvimento Científico e Tecnológico) to J.O.B. and M.L.C. The authors' thanks are also due to Dimítri de Araújo Costa, José Eriberto De Assis, Rudy Camilo Nunes and Joafrâncio Pereira de Araújo for their help with the figures.

\section{REFERENCES}

ALBERTONI, E. F.; PALMA-SILVA, C.; ESTEVES, F. A Larvae and post-larvae of Penaeidae and Palaemonidae in coastal lagoons of the north of Rio de Janeiro (Macaé, RJ). Rev. Bras. Biol., v. 59, p. 109-117, 1999.

ALBERTONI, E.; PALMA-SILVA, C.; ESTEVES, F. A Crescimento e fator de condição de Farfantepenaeus brasiliensis (Latreille) e $F$. paulensis (Pérez-Farfante) (Crustacea, Decapoda, Penaeidae) em uma lagoa costeira tropical do Rio de Janeiro, Brasil.Rev. Bras. Zool., v. 20, p. 409-418, 2003.

BEMVENUTI, C. E.; ANGONESI, L. G.; GANDRA, M. S. Effects of dredging operations on soft bottom macrofauna in a harbor in the Patos lagoon estuarine region of the Southern Brazil. Braz. J. Biol., v. 65, p. 573-581, 2005.

BRANCO, J. O. Biologia e pesca do camarão sete-barbas Xiphopenaeus kroyeri (Heller) (Crustacea, Penaeidae), na Armação do Itapocoroy, Penha, Santa Catarina, Brasil. Rev. Bras. Zool., v. 22, p. 1050-1062, 2005.
BRANCO, J. O.; MASUNARI, S. Reproductive ecology of the blue crab, Callinectes danae Smith, 1869 in the Conceição Lagoon system, Santa Catarina Isle, Brazil. Rev. Bras. Biol., v. 60, p. 17-27, 2000.

BRANCO, J. O.; MORITZ JR., H. C. Alimentação natural do camarão sete-barbas (Xiphopenaeus kroyeri), na Armação do Itapocoroy, Penha, SC. Rev. Bras. Zool., v. 18 , p. 53-61, 2001.

BRANCO, J. O.; VERANI, J. R. Aspectos bioecológicos do camarão-rosa Penaeus brasiliensis Latreille (Natantia, Penaeidae) da Lagoa da Conceição, Florianópolis, Santa Catarina, Brasil. Rev. Bras. Zool., v. 15, p. 45-351, 1998a.

BRANCO, J. O.; VERANI, J. R. Estrutura populacional do camarão-rosa Penaeus paulensis Latreille (Natantia, Penaeidae) na Lagoa da Conceição, Santa Catarina, Brasil. Rev. Bras. Zool., v. 15, p. 353-364. 1998b.

BRANCO, J. O.; LUNARDON-BRANCO, M. J.; VERANI, J. R.; SCHVEITZER, R.; SOUTO, F. X.; VALE, W. G.; Natural diet of Callinectes ornatus Ordway, 1863 (Decapoda, Portunidae) in the Itapocoroy inlet, Penha, SC, Brazil. Braz, Arch. Biol. Tecn., v. 45, p. 35-40, 2002.

BRANFORD, J. R. Sediment and the distribution of penaeid shrimp in the Sudanese Red Sea. Estuar. Coast. Shelf Sci., v. 13, p. 349-354, 1981.

CASTRO, R. H.; COSTA, R. C.; FRANSOZO, A.; MANTELATTO, F. L. M. Population structure of the seabob shrimp Xiphopenaeus kroyeri (Heller, 1862) (Crustacea: Penaeoidea) in the littoral of São Paulo, Brazil. Sci. Mar., v. 69, p. 105-112, 2005.

CHAGAS-SOARES, F.; PEREIRA, O. M.; SANTOS, E. D. Contribuição ao ciclo biológico de Penaeus schmitti Burkenroad, 1936, Penaeus brasiliensis, Latreille, 1817 e Penaeus paulensis Pérez-Farfante, 1967, na região lagunar-estuarina de Cananéia, São Paulo, Brasil. Bolm Inst. Pesca, v. 22, p. 49-59, 1995.

COURTEMANCH, D. L. Bridging the old and new science of biological monitoring. J. N. Am. Benthol. Soc., v.13, p. 117-121, 1994.

D’INCAO, F. 1991. Pesca e biologia de Penaeus paulensis na Lagoa dos Patos, RS, Brasil. Atlântica, v. 13, p. 159169.

D'INCAO, F. Mortalidade de Penaeus (Farfantepenaeus) paulensis Pérez-Farfante, 1967 no estuário da Lagoa dos Patos, Rio Grande do Sul, Brasil (Crustacea, Penaeidae). Atlântica, v. 12, p. 73-84, 1990.

D’INCAO, F.; CALAZANS, D. K. Relações biométricas do "camarão rosa" Penaeus paulensis Pérez Farfante, 1967 na Lagoa dos Patos, RS, Brasil. Atlântica, v. 3, p. 57-66, 1978.

D'INCAO, F.; VALENTINI, H.; RODRIGUES, L. F. Avaliação da pesca de camarões nas regiões sudeste e sul do Brasil: 1965 - 1999. Atlântica, v. 24, p. 103-116, 2002

FORBES, A. T.; CYRUS, D. P. Recruitment and origin of penaeid prawn postlarvae in two south-east African estuaries. Estuar. coast. Shelf Sci., v. 33, p. 281-289, 1991.

GUSMÃO J.; LAZOSKI, C.; SOLÉ-CAVA, A. M. Population genetic structure of Brazilian shrimp species (Farfantepenaeus sp., F. brasiliensis, F. paulensis and Litopenaeus schmitti: Decapoda: Penaeidae). Genet. Mol. Biol., v. 28, p. 165-171, 2005. 
LEITE, N. O.; PETRERE JR., M. Stock assessment and fishery management of the pink-shrimp Farfantepenaeus brasiliensis Latreille, 1970 and $F$. paulensis PérezFarfante 1967 in southeast Brazil (23 to $\left.28^{\circ} \mathrm{S}\right)$. Braz. J. Biol., v. 66, p. 263-277, 2006a.

LEITE, N. O.; PETRERE JR., M. Growth and mortalities of the pink-shrimp Farfantepenaeus brasiliensis Latreille, 1970 and $F$. paulensis Pérez-Farfante 1967 in southeast Brazil. Braz. J. Biol., v.66, p. 523-536, 2006 b.

LINS-OLIVEIRA, J. E. Estudo do sex-ratio entre Penaeidae através da utilização de um modelo de regressão linear adaptado. Bolm Dep. Oceanogr. Limnol., v. 9, p. $67-$ 74, 1996.

LOEBMANN D.; VIEIRA, J. P. O. impacto da pesca do camarão-rosa Farfantepenaeus paulensis (PérezFarfante) (Decapoda, Penaeidae) nas assembléias de peixes e siris do Parque Nacional da Lagoa do Peixe, Rio Grande do Sul, Brasil. Rev. Bras. Zool., v.23, p. 10161028, 2006.

LUCHMANN, K. H.; FREIRE, A. S., FERREIRA, N. C.; DAURA-JORGE, F. G.; MARQUES, M. R. F. Spatial and temporal variations in abundance and biomass of penaeid shrimps in the subtropical Conceição lagoon, southern Brazil. J. mar. biol. Ass. U. K., v. 88, p. 293299, 2008.

MELLO, J. T. C. Estudo populacional do "camarão-rosa" Penaeus brasiliensis (Latreille, 1817) e Penaeus paulensis Pérez-Farfante 1967. Bolm Inst. Pesca, v. 2, p. 19-65, 1973.

MMA (Ministério do Meio Ambiente). Instrução Normativa n. 5. Rio de Janeiro: Diário Oficial da União, 2004.

MOLLERI, G. S. F.; BONETTI, J. Caracterização morfosedimentar da Baía Sul/SC com base em um sistema de informações geográficas. An. Seg. CONGRESSO BRASILEIRO DE OCEANOGRAFIA, 2., Guarapari, 2005. Anais..., v. 1, 2005.

MOURA, G. F.; MELO, G. N.; SAMPAIO, J. A. A. Estudos biométricos das espécies de camarões peneídeos de importância econômica no litoral de Lucena, Paraíba. Bolm Técn. Cient. Centr. Pesq. Nord., v. 11, p.189210, 2003.

NAKAGAKI, J. M.; NEGREIROS-FRANSOZO, M. L.; FRANSOZO, A. Composição e abundância de camarões marinhos (Crustacea, Decapoda, Penaeidae) na Enseada de Ubatuba (SP), Brasil. Arch. Biol. Tecn., v. 38, p. 583-591, 1995.

NEWELL, R. C.; SEIDERER, L. J.; HITCHCOCK, D. R. The impact of dredging works in coastal waters: A review of the sensitivity to disturbance and subsequent recovery of biological resources on the sea bed. Ocean. mar. Biol., v. 36, p. 127-178, 2003.

NEWELL, R. C.; SEIDERER, L. J.; SIMPSON, N. M.; ROBINSON, J. E. Impacts of marine aggregate dredging on benthic macrofauna off the south coast of the United Kingdom. J. coast. Res., v. 20, p. 115-125, 2004.

NORRIS, R. H. Biological monitoring: the dilemma of data analysis. J. N. Amer. Benthol. Soc., v. 14, p. 440-450, 1995.

PÉREZ-CASTAÑEDA, R.; DEFEO, O. Population variability of four sympatric penaeid shrimps (Farfantepenaeus spp.) in a tropical coastal lagoon of Mexico. Estuar. coast. Shelf Sci., v. 52, p. 631-641, 2001.
PÉREZ-CASTAÑEDA， R.; DEFEO， O. Growth and mortality of transient shrimp populations (Farfantepenaeus spp.) in a coastal lagoon of Mexico: role of the environment and density-dependence. ICES J. Mar. Sci., v. 62, p. 14-24, 2005.

PÉREZ-FARFANTE, I. Diagnostic characters of juveniles of the shrimps Penaeus aztecus aztecus, P. duorarum duorarum, and $P$. brasiliensis (Crustacea, Decapoda, Penaeidae). Spec. Sci. Rep. Fish., v. 599, p. 1-26, 1970.

PÉREZ-FARFANTE, I. Shrimps and prawns. In: FISHER, W. (Ed.). FAO species identifications sheets for fishery purposes. Western Central Atlantic (Fishery Area 31). Rome: FAO, 1978, v. 6, p. 40.

RESGALLA, J. R. C. Estudo de impacto ambiental sobre a comunidade do zooplâncton na enseada do Saco dos Limões, Baía-Sul da Ilha de Santa Catarina, Brasil. Atlântica, v. 23, p. 5-16, 2001.

ROBERT, R.; BORZONE, C. A.; NATIVIDADE, C. D. Os camarões da fauna acompanhante na pesca dirigida ao camarão sete-barbas (Xiphopenaeus kroyeri) no litoral do Paraná. Bolm Inst. Pesca, v. 33, p. 237-246, 2007.

SANTOS, E. P. Dinâmica de populações aplicada à pesca e piscicultura. São Paulo: Editora da Universidade de São Paulo, 1978.

SCHETTINI, C. A. F.; PEREIRA FILHO, J.; SPILLERE, L. Caracterização oceanográfica e biogeoquímica dos estuários dos Rios Tavares e Defuntos, Reserva Extrativista de Pirajubaé, Florianópolis, SC. Not. Técn. Fac. Ciênc. Mar, v. 4, p. 11-28, 2000.

SIGNORET, M. Abundancia, tamaño y distribución de camarones (Crustacea, Penaeidae) de la Laguna de Términos, Campeche y su relación con algunos factores hidrológicos. An. Inst. Biol. Univ. nac. autón. Mexico, v. 45, p. 119-140, 1974.

SOUZA-CONCEIÇÃO, J. M.; RODRIGUES-RIBEIRO, M.; CASTRO-SILVA, M. A. Dinâmica populacional, biologia reprodutiva e ictioplâncton de Cetengraulis edentulus Cuvier (Pisces, Clupeiformes, Engraulidae) na Enseda do Saco dos Limões, Florianópolis, Santa Catarina, Brasil. Rev. Bras. Zool., v. 22, p. 953-961, 2005.

VALENTINI, H.; D' INCAO, F.; RODRIGUES, L. F.; REBELO NETO, J. E.; RAHN, E. Análise da pesca do camarão rosa (Penaeus brasiliensis e Penaeus paulensis) nas regiões sudeste e sul do Brasil. Atlântica, v. 13, p. 143-157, 1991.

VAZZOLER, A. E. A. M. Biologia da reprodução de peixes teleósteos: teoria e prática. Maringá: Editora da Universidade Estadual de Maringá, 1996.

VILLELA, M. J.; COSTA, P. A.; VALENTIN, J. L. Crescimento e mortalidade de juvenis do camarão-rosa (Penaeus brasiliensis Latreille, 1817) na Lagoa do Araruama, Rio de Janeiro. Rev. Bras. Zool., v. 57, p. 487-499, 1997.

VON DOLAH, R. F.; CALDER, D. R.; KNOTT, D. M. Effects of dredging and open-water disposal on benthic macroinvertebrates in a South Carolina estuary. Estuaries, v.7, p. 28-37, 1984.

ZAR, J. Biostatistical analysis. $4^{\text {th }}$ ed. Upper Sadle River, N. J.: Prentice-Hall, 1999.

(Manuscript received 22 February 2011; revised 31 May 2011; accepted 04 July 2011) 